\title{
A Novel Metabotropic Glutamate Receptor Expressed in the Retina and Olfactory Bulb
}

\author{
Robert M. Duvoisin, ${ }^{1,2}$ Congxiao Zhang, ${ }^{1,2}$ and Katrina Ramonell' \\ ${ }^{1}$ Margaret M. Dyson Vision Research Institute, Department of Ophthalmology and ${ }^{2}$ Graduate Program in \\ Neuroscience, Cornell University Medical College, New York, New York 10021
}

\begin{abstract}
A novel metabotropic glutamate receptor, mGluR8, was identified by screening a mouse retina cDNA library. This receptor is most related to mGluR4, mGluR7, and mGluR6 $(74 \%, 74 \%$, and $70 \%$ identical amino acid residues, respectively). Similar to these receptors, stimulation by L-glutamate or L-2-amino-4-phosphonobutyrate (L-APB) of Chinese hamster ovary $(\mathrm{CHO})$ cells stably transfected with mGluR8 result in the inhibition of forskolin-stimulated adenylyl cyclase. In situ hybridization studies revealed a strong expression of the mGluR8 gene in the olfactory bulb, accessory olfactory bulb, and mammillary body. A weaker expression was found in the retina, and in scattered cells in the cortex and hindbrain. During development, the distribution of mGluR8 expression was more widespread.

These results extend the diversity of metabotropic glutamate receptors in the CNS. Because at least two APB receptors are expressed in the retina, the use of this drug to block selectively the ON pathway needs to be reconsidered. The pharmacology and expression of mGluR8 in mitral/tufted cells suggest it could be a presynaptic receptor modulating glutamate release by these cells at their axon terminals in the entorhinal cortex.
\end{abstract}

[Key words: L-2-amino-4-phosphonobutyrate (APB, L-AP4), glutamate receptor, metabotropic receptor, retina, olfactory bulb, ontogenesis, ON pathway]

The actions of glutamate, the major excitatory neurotransmitter in the vertebrate CNS, are mediated through glutamate receptors (GluRs). There are two broad classes of GluRs. One class, the ionotropic receptors, are ligand-gated ion channels whose response to selective agonists define the NMDA, $\alpha$-amino-3-hydroxy-5-methylisoxasole-4-propionate (AMPA) and kainate subtypes (Monaghan et al., 1989). They are assembled from an as yet undetermined number of subunits encoded by related gene families (reviewed by Nakanishi, 1992; Seeburg et al., 1993; Hollmann and Heinemann, 1994).

In contrast, metabotropic glutamate receptors (mGluRs) are coupled through $G$ proteins to second messenger pathways.

\footnotetext{
Received Junc 23, 1994; rcvised Nov. 2, 1994; accepted Nov. 8, 1994.

We thank Drs. Cathy Bowes and Debora Farber for the gift of a mouse retina cDNA library, Drs. Moses Chao, Anna Francesconi, Arlene Hirano, Thom IIughes, Peter MacLeish, and Jean-Plilippe Pin for helpful discussions. This work was supported by the National Institute of Health (Grant EY09534). R.M.D. is the recipient of a Research to Prevent Blindness Career Development Award.

Correspondence should be addressed to Robert Duvoisin, Dyson Vision Research Institute, F-835, Cornell University Medical College, 1300 York Avenue, New York, NY 10021 .

Copyright $(C) 1995$ Society for Neuroscience $0270-6474 / 95 / 153075-09 \$ 05.00 / 0$
}

They are formed by a single polypeptide, predicted to span the plasma membrane seven times. Thus, they would share a common structural architecture with the $\mathrm{G}$ protein-coupled receptor superfamily, even though at the primary structure level, no homology is apparent. Molecular cloning has identified seven distinct metabotropic receptors termed mGluR1 through mGluR7 (Houamed et al., 1991; Masu et al., 1991; Tanabe et al., 1992; Abe et al., 1993; Nakajima et al., 1993; Okamoto et al., 1994; Saugstad et al., 1994). Recently, a Ca ${ }^{2+}$-sensing receptor, identified from a bovine parathyroid cDNA library, has been found to be related to mGluRs, thus expanding this gene family (Brown et al., 1993). Metabotropic GluRs can be classified into three groups according to their sequence similarities, pharmacological properties, and preferred signal transduction mechanism (Nakanishi, 1992): group I receptors, mGluR1 and mGluR5, are most strongly activated by quisqualate and are coupled to phosphoinositol turnover; group II receptors, mGluR2 and mGluR3, are most sensitive to trans-1-aminocyclopentane1,3-dicarboxylic acid (trans-ACPD); and group III receptors, mGluR4, mGluR6, and mGluR7, are selectively activated by L-2-amino-4-phosphonobutyrate (L-APB, or L-AP4). Group II and III receptors, when expressed in transfected fibroblast cell lines, are coupled to the inhibition of adenylyl cyclase.

Because of detailed anatomical, physiological, and pharmacological studies, the retina is well suited to analyze the relationship between GluR diversity and neural function. For example, an APB-activated mGluR, most likely mGluR6 (Nakajima et al., 1993; Nomura et al., 1994), plays a critical role in the retina in generating the depolarizing response of $\mathrm{ON}$ bipolar cells which is at the origin of the ON pathway (Slaughter and Miller, 1981). Many studies have used APB to block selectively ON bipolar cells and analyze the function of the ON pathway in vision processing (reviewed by Schiller, 1992).

To better understand the role of glutamatergic neurotransmission in the retina in particular, and in the CNS in general, ultimately all GluRs need to be identified, their distribution mapped and their pharmacological and physiological characteristics determined. By screening mouse retina cDNA libraries, we have identified a novel metabotropic receptor, sensitive to $\mathrm{APB}$, which we are naming mGluR8. This is the second mGluR activated by APB found in retina. The effects of this drug in this tissue are thus likely to be more complex than previously thought, and not limited to blocking the ON pathway. Until we understand better the role of mGluR 8 in retinal function, caution is needed in interpreting experiments using APB in the retina.

\section{Materials and Methods}

Degenerate primer $P C R$, construction and screening of $C D N A$ libraries. Two approaches were used to identify additional mGluRs expressed in 
retina: PCR using degenerate primers and screening of retina cDNA libraries. For PCR, the following primers were synthesized on a PCRmate (Applied Biosystems, Foster City, CA): 5'-TACCTG(C/G)TGGA(C/ T)GAGTTCAC(T/C)TG, 5'-ATGCAGGTGGTGTACATGGT(A/G)AA. PolyA ${ }^{+}$RNA was isolated from dissected retina of C57BL/6 mice using the QuickPrep mRNA Purification Kit (Pharmacia, Piscataway, NY) and cDNA was synthesized using oligo(dT) as primer. Following RNA lenplate removal with RNaseH (Boehringer Mannheim, Indianapolis, IN), the cDNA was amplified by PCR; 740 bp long PCR products were cloned into pBluescriptSK $(-)$ (Stratagene, La Jolla, CA), and their nucleotide sequences were determined (Sequenase, United States Biochemicals, Cleveland, $\mathrm{OH}$ ). Sequences encoding mGluR1, mGluR3, and two previously unidentified receptors were isolated.

The alternate approach was to screen two mouse retina cDNA libraries. One was a generous gift by Drs. Cathy Bowes and Debora Farber (University of California, Los Angeles; Bowes et al., 1989). The other was constructed using the $\lambda Z A P-c D N A$ Cloning Kit (Stratagene) and polyA ${ }^{+}$RNA isolated as described above. Approximately $10^{6}$ phages from the first library were screened using a mixed probe ${ }^{32} \mathrm{P}-$ labeled by random priming (Boehringer Mannheim). The probes were prepared from PCR fragments encoding the seven transmembrane domain of mGluR1 and mGluR3. The screening was performed under medium stringency conditions: the filters were hybridized overnight at $65^{\circ} \mathrm{C}$ in $5 \times$ SSC, $0.5 \%$ SDS, $0.5 \mathrm{mg} / \mathrm{ml}$ denatured sonicated herring sperm DNA and $1 \times$ Denhardt's solution with $2 \times 10^{5} \mathrm{cpm} / \mathrm{ml}$ of each probe. Washings were done at room temperature in $2 \times$ SSC and $0.1 \%$ SDS. SSC and Denhardt's solution are as defined by Sambrook et al. (1986). The cDNA insert of four positive clones was excised in vivo (Short et al., 1988; Duvoisin et al., 1989), plasmid DN $\Lambda$ was prepared, and analyzed by Southern blot to identify fragments hybridizing to the mGluR probe. These fragments were subcloned into pBluescriptSK $(-)$ and their nucleotide sequences were determined. One of the positive clones was shown to encode the mouse mGluR1 gene, the sequence of another was unrelated to metabotropic receptors, whereas the two remaining clones were identical and their sequence overlapped one of the novel sequences identified by degenerate primer PCR. The cDNA insert was not full-length and a PCR fragment corresponding to bases 17912236 of the final sequence (Fig. 1) was used to screen both retina cDNA libraries. Hybridization conditions were the same as above, washings were at high stringency each at $65^{\circ} \mathrm{C}$ for $30 \mathrm{~min}$; twice in $2 \times \mathrm{SSC}$, $0.1 \%$ SDS; once in $0.5 \times$ SSC, $0.1 \%$ SDS; and a final wash in $0.2 \times$ SSC, $0.1 \%$ SDS. In this way three additional clones were isolated. The nucleotide sequence of segments homologous to mGluR coding regions was determined using primers synthesized according to previously established sequence.

Construction of a full-length clone and functional expression in $\mathrm{CHO}$ cells. The 5'-RACE-PCR kit (GIBCO/Bethesda Research Labs, Gaithersburg, MD) was used to clone the remaining portion of the coding region. Two rounds of PCR were needed. After the first round, a sample of the PCR product was used for a Southern blot with an end-labeled nested primer as probe to determine the size of the sought after DNA piece. The remainder of the PCR was size fractionated on a $1 \%$ agarose gel, eluted and a second round of PCR was done using the nested and anchor primers. The PCR product was digestcd with SalI (a sitc contained in the anchor primer) and $K p n I$ (a site identified in the cDNAderived sequence) and size-fractionated on an agarose gel. The fragment was ligated into similarly digested pBluescriptSK(-). The full-length CDNA insert was constructed from pieces of the RACE-PCR, and two overlapping cDNA clone-derived sequences and cloned into pGEM3Z (Promega, Madison, WI). To verify the final construct, at least one strand was sequenced over the full length. Between the sequences of the cDNA clones and the RACE-PCR fragment, the nucleotide sequence was determined on both strands throughout. Nucleotide sequence analysis was facilitated by the use of the GCG software package (Devereux et al., 1984).

For expression studies the G/C tail generated during the RACE-PCR and approximately 450 bases of $5^{\prime}$ untranslated region were removed. The Apal-SacI fragment was cloned into pCMV5 (Chenl et al., 1991). Chinese hamster ovary $(\mathrm{CHO})$ cells were transfected with this construct together with one tenth the amount of pSVneo (Southern and Berg, 1982). These cells were maintained in DMEM with $10 \%$ dialyzed fetal

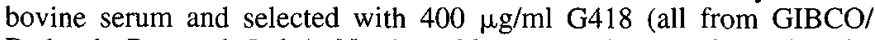
Bethesda Research Labs). Northern blots were done to determine the highest expressing cell lines. Cells were plated at $1.5 \times 10^{5}$ cells per well in 12 well plates and grown for $2 \mathrm{~d}$. Medium was replaced by 1
mM 3-isobutyl-1-methylxanthine (IRMX) in phosphate-buffered saline

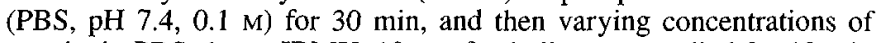
agonist in PBS, $1 \mathrm{mM}$ IBMX, $10 \mu \mathrm{M}$ forskolin were applied for $10 \mathrm{~min}$ at $37^{\circ} \mathrm{C}$. The reaction was stopped and the cells collected and lysed in $66 \%$ ethanol, 4 mM EDTA. Cyclic AMP concentrations were measured in triplicate using a cAMP detection kit (Amersham, Arlington Heights, IL). Each experinent was done at least three times. L-APB and quisqualate were obtained from Cambridge Research Chemicals (Cambridge, UK); (1S,3R)-ACPD from Tocris Neuramin (Buckhurst Hill, UK). IBMX, forskolin, L-glutamate, and ibotenate were from Sigma (St. Louis, MO).

In situ hybridization. The full-length cDNA clone in pGEM3Z was linearized with $A p a \mathrm{I}$ or SacI, transcribed in vitro using T7 or SP6 polymerase and ${ }^{35}$ S-UTP (New England Nuclear, Boston, MA) to generate antisense and sense probes, respectively. Probes were hydrolyzed to about 200-400 bases in length according to Cox et al. (1984), and used at about $5 \times 10^{6} \mathrm{cpm} / \mathrm{ml}$. Adult C57BL/6 mice (Charles River, Wilmington, $\mathrm{M} \Lambda$ ) were sacrificed with $\mathrm{CO}_{2}$, and their brain and eyecups were fixed in $4 \%$ paraformaldehyde (PFA) in PBS for 3-4 hr. Sixteen days following the occurrence of a vaginal plug, pregnant mice were sacrificed with $\mathrm{CO}_{2}$ and embryos were removed and frozen on dry ice. Tissues were cryoprotected in $30 \%$ sucrose in PBS and embedded in O.C.T. Compound (Miles, Elkhart, IN); $12 \mu \mathrm{m}$ thick sections were cut on a cryostat, collected on gelatin- and polylysine-coated slides, and fixed in 4\% PFA-PBS. Following hybridizations and washings, as previously described (Hughes et al., 1992), the slides were dipped in Kodak NTB-2 nuclear emulsion diluted in water $(1: 1)$, stored in the dark for 4-8 weeks, developed in D-19, and fixed (Kodak, Rochester, NY). Sections were covered with glycerin and PBS (1:1) and coverslipped. Final washings were done also at higher stringency in $20 \%$ formamide, $0.1 \times$ $\mathrm{SSC}, 1 \mathrm{~mm} \mathrm{DTT}$ at $55^{\circ} \mathrm{C}$ and produced similar patterns of expression.

\section{Results}

Molecular characterization of a novel metabotropic glutamate receptor

To identify additional metabotropic reccptors whosc cxpression might be restricted to the retina, two approaches were used. Mouse retina polyA ${ }^{+}$RNA was reverse transcribed and amplified (RT-PCR) using degenerate oligonucleotide primers derived from two conserved amino acid sequence stretches in the extracellular domain and in the putative sixth transmembrane segment. PCR fragments of the expected 742 bp size were cloned, and their nucleotide sequence was determined. Sequences encoding mGluR1, mGluR3, and two previously unidentified receptors were isolated.

In a separate approach, a mouse retina cDNA library (Bowes et al., 1989) was screened using two PCR fragments encoding the seven transmembrane region of mGluRl and mGluR3 as probes (Houamed et al., 1991; Masu et al., 1991; Tanabe et al., 1992). One of the $\lambda$ recombinant phages isolated contained a sequence encoding a new member of the mGluR family; it was identical to one of the two sequences identified by degenerate primer-PCR. Nucleotide sequencing revealed that this cDNA clone, although large enough to contain a complete receptor, only encoded the carboxy-terminal region of this receptor. This was most likely due to a cloning artifact. A PCR fragment derived from this partial cDNA clone was used to screen additional retina libraries, and three overlapping cDNA inserts were isolated. In addition, the RACE-PCR procedure (Frohman et al., 1988) was used to clone the remaining $5^{\prime}$ region.

For functional expression studies and to provide a longer probe for in situ hybridization experiments, a full-length clone was engineered from parts of the RACE-PCR product and two overlapping cDNA clones. The resulting construct contains the entire coding region. Its nucleotide sequence is shown in Figure 1 , together with the deduced amino acid sequence.

From the assigned initiation codon, which is in conformity 
1 ATGGTTTGTGAGGGAAAGCGCTCAACCTCTTGCCCTTGTTTCTTCCTTTTGACTGCCAAGTTCTACTGGATCCTCACAATGATGCAAAGAACTCACAGCCAGGAGTATGCCCATTCCATC 1 MetValCysGI UGlyLysArgSerThrSerCysProCysPhePheLeuLeuThrAlaLysPheTyrTrpI leLeuThrMetMetGlnArgThrHisSerGlnGIUTyrAlaHisSerI le

121 CGCCTGGATGGGGACATCATTTTGGGGGTCTTTTTCCTGTTCATGCCAAGGGAGAAAGAGGGGTGCCTTGTGGGGACCTGAAGAAGGAAAAGGGCATCCACAGACTTGAGGCCATGCTT

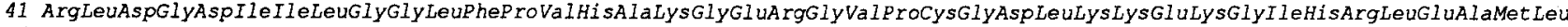

241 TATGCAATCGACCAGACTAATAAGGACCCCGATCTCCTCTCCAATATCACTCTGGGTGTCCGGATCCTTGACACATGT TCCAGGGACACCTATGCTTTGGAGCAGTCACTAACCTTCGTG 81 TyrAlaIleAspGinThrAsnLysAspProAspLeuLeuSerAsnI leThrLeuGlyValArgIleLeuAspThrCysSerArgAspThrTyrAlaLeuGluGInSerLeuThrFheVal A

361 CAGGCACTGATAGAGAAAGACGCGTCTGACGTGAAGTGTGCTAATGGAGACCCACCCATATTCACCAAGCCCGACAAGATTTCTGGTGTCATAGGTGCTGCAGCAAGCTCCGTGTCCATC

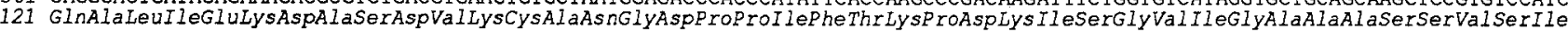

481 ATGGTGGCTAACATTTTAAGACTTTTTAAGATACCTCAGATTAGCTATGCATCTACAGCCCCAGAGCTAAGTGACAACACCAGGTATGATTTCTTTTCTCGGGTGGTCCCGCCTGACTCC 161 MetValAlaAsnI leLeuArgLeuPheLysI leProGInI leSerTyrAlaSerThrAlaP roGluLeuSerAspAsnThrArgTyrAspPhePheSERArgValValP roProAspSer

601 TACCAAGCCCAAGCCATGGTGGACATTGTGACAGCCCTGGGATGGAATTATGTGTCAACACTGGCTTCCGAGGGGAACTATGGAGAGAGTGGTGT TGAGGCCTTCACTCAGATCTCAAG

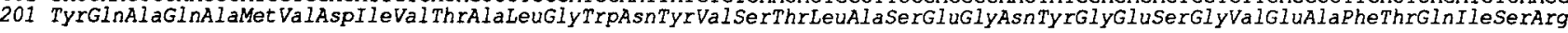

721 GAGATTGGTGGTGTTTGCATTGCTCAATCACAGAAAATCCCACGTGAACCAAGACCTGGAGAATTCGAAAAAATTATCAAACGCCTGCTGGAGACACCCAACGCTCGCGCAGTGATTATG

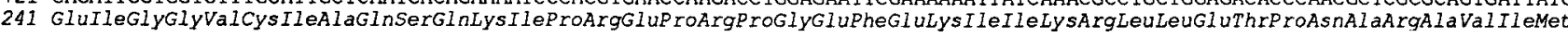

841 TTTGCCAATGAGGATGACATCAGGGGGATATTGGAAGCAGCAAAAAAATTAAACCAGAGTGGGCATTTTCTATGGATTGGCTCAGATAGTTGGGGATCCAAAATAGCACCTGTCTATCAG

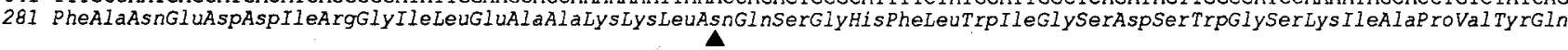

961 CAGGAGGAGATCGCCGAAGGAGCTGTGACAATTTTGCCCAAAAGAGCATCAATTGATGGGTTTGACCGATACTTTAGAAGCCGAACTCTTGCCAATAATCGAAGAAATGTGTGGTTTGCA 321 GlnGlugluIleAlaGluGlyAlaVal ThrI leLeuProLysArgAlaSerIleAspGlyPheAspArgTyrPheArgSerArgThrLeuAlaAsnAsnArgArgAsnVal TrpPheAla

1081 GAATTTTCGGAGGGGAATTTTGGATGCAAATCAGGATCACATGGGAAGAGGAACAGTCATATAAAGAAATGCACAGGGCTGGAGCGAATTGCACGGGATTCATCTTACGAACAAGAAGGA

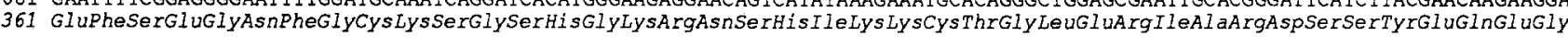

1201 AAGGTTCAATT TGTAATTGATGCAGTGTATTCCATGGCTTATGCACTGCACAACATGCACAAAGAACTCTGCCCTGGTTACATAGGCCTTTGCCCAAGGATGGTTACCATCGATGGGAAA

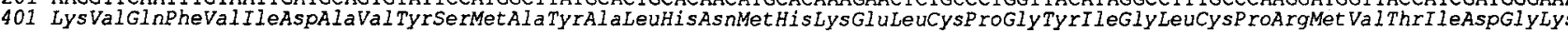

1321 GAGCTACTGGGTTACATCAGGGCCGTGAATTTAATGGCAGCGCTGGTACACCTGTCACTTTTAATGAGAATGGAGATGCTCCGGGACGCTACGATATCTTCCAATATCAGATAAACAAC

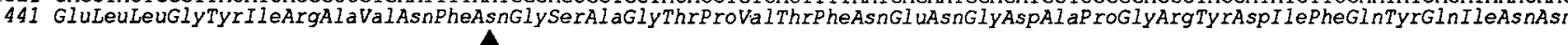

1441 AAAAGTACAGAATACAAAATCATCGGCCACTGGACCAATCAACTTCACCTAAAAGTGGAAGACATGCAGTGGGCTAATAGAGAGCACACGCACCCAGCATCTGTCTGCAGCCTGCCGTGC

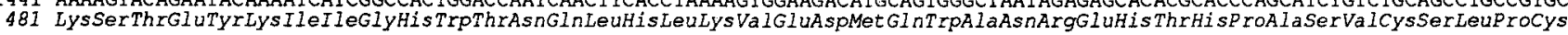

1561 AAGCCTGGGGAGAGGAAGAAAACCGTGAAAGGGGTCCCTIGCTGCTGGCACTGTGGACGCTGCGAGGGTTATAACTACCAGGTGGACGAACTCTCCTGTGAACTCTGCCCTTTGGATCAG

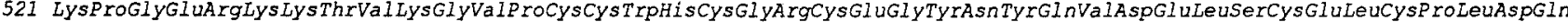

1681 AGACCAAACATCAACCGCACTGGCTGCCAGAGGATCCCCATCATCAAGTTGGAGTGGCATTCACCCTGGGCCGTGGTACCTGTGCTCATAGCAATATTGGGAATCATTGCCACCACCTTT

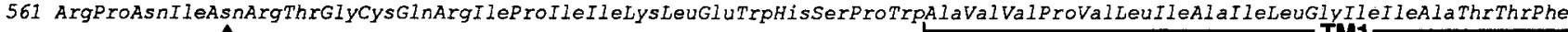

1801 GTGATTGTGACCTTTGTCCGCTATAATGACACACCAATCGTGAGAGCTTCTGGGCGGGAACTTAGTTATGTGCTCCTAACGGGGATTTTTCTCTGTTACTCAATCACTTTTTTGATGATT 601 ValI leVaIThrPheValArgTyrAsnAspThrP roIleValArgAlaSerGlyArgGluLeuSerTyrVal LeuLeuThrGly I lePheLeuCysTyrSerIleThrPheLeuMet I le

1921 GCGGCACCTGACACAATCATCTGCTCTTTCCGAAGGATCTTCCTGGGACTTGGTATGTGTTTCAGCTATGCAGCACTTTTGACCAAAACAAACCGTATCCACCGAATATTCGAGCAAGGG

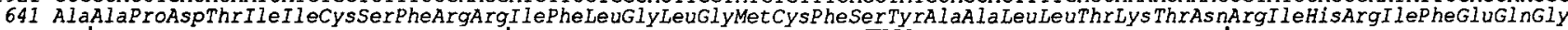

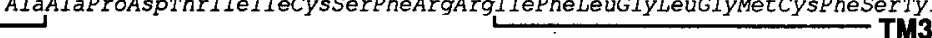

2160 AAGAAATCTGTCACAGCACCTAAGTTCATCAGCCCAGCATCCCAGCTGGTGATCACCTTCAGCCTCATCTCCGTACAGCTCCTTGGAGTGTTTGTGTGGTTTGTCGTGGATCCCCCCCAC 681 LysLysSerValThrAlaProLysPheTleSerProAlaSerGInLeuValileThrPheSerLeuIleSerValGlnLeuLeuGlyValPheVaITrpPheValValAspProProHis TM4

2161 ACCATCATTGACTATGGAGAACAGCGAACACTGGATCCCGAGAACGCCAGGGGAGTGCTCAAGTGTGACATTTCCGATCTGTCACTCATTTGTTCACTGGGATACAGTATCCTCCTGATG 721 ThrIleI leAspTy

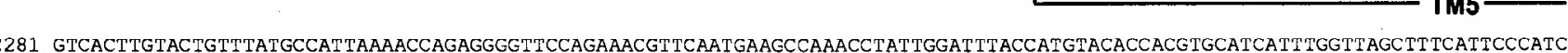

761 Val ThrCysThrVal TyrAlaI leLysThrArgGlyValProGluThrPheAsnGIuAlaLysProIleGlyPheThrMet TyrThrThrCysI leIleTrpLeuAlaPheIleProIle

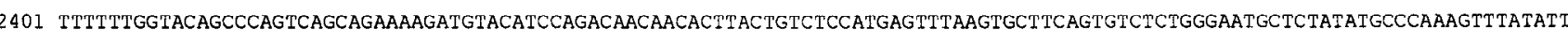
801 PhePheGlyThrAlaGlnSerAlaGluLysMet TyrI leGInThrThrThrLeuThrValSerMet SerLeuSerAlaSerVal SerLeuGl YMetLeuTyrMetProLysVal TyrI le TM7

2521 ATAATTTTTCATCCAGAGCAGAACGTTCAAAAACGCAAGAGAAGCTTCAAGGCTGTGGTCACGGCCGCTACCATGCAAAGCAAACTGATCCAAAAGGGAAATGACAGACCAAACGGCGAG 841 IleIlePheHisP roGluglnAsnValGlnLysArgLysArgSerPheLysAlaVaIValThrAlaAlaThrMet GlnSerLysLeuI leGlnLysGlyAsnAspargProAsnGlyGlu

2641 GTGAAAAGTGAACTCTGTGAGAGTCTTGAAACCAACACTTCTTCTACCAAGACAACATACATCAGCTACAGTGATCATTCAATCTGAACAGGGAGATGGCACCATCTGAAGGAAGGTGCT

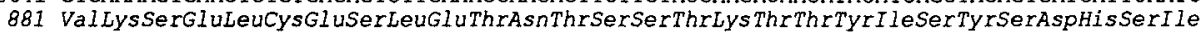

Figure 1. Nucleotide sequence and deduced amino acid sequence of mGluR8. The seven putative transmembrane segments and leader peptide indicated were assigned based on hydrophobicity analysis and alignment with the previously published seven mGluRs. Potential N-linked glycosylation sites are indicated by solid triangles, potential phosphorylation sites by asterisks. GenBank accession number U17252.

with the consensus sequence for translation initiation (Kozak, 1986) and is also the first in-frame methionine codon following a non-sense codon at position -93 (not shown), to the termination codon at position 2725 , an open reading frame encodes a 908 residue protein. Analysis of the deduced amino acid sequence reveals features characteristic of a mGluR, including seven putative transmembrane segments. By analogy with other mGluRs, the amino-terminal residues are likely to form a signal 


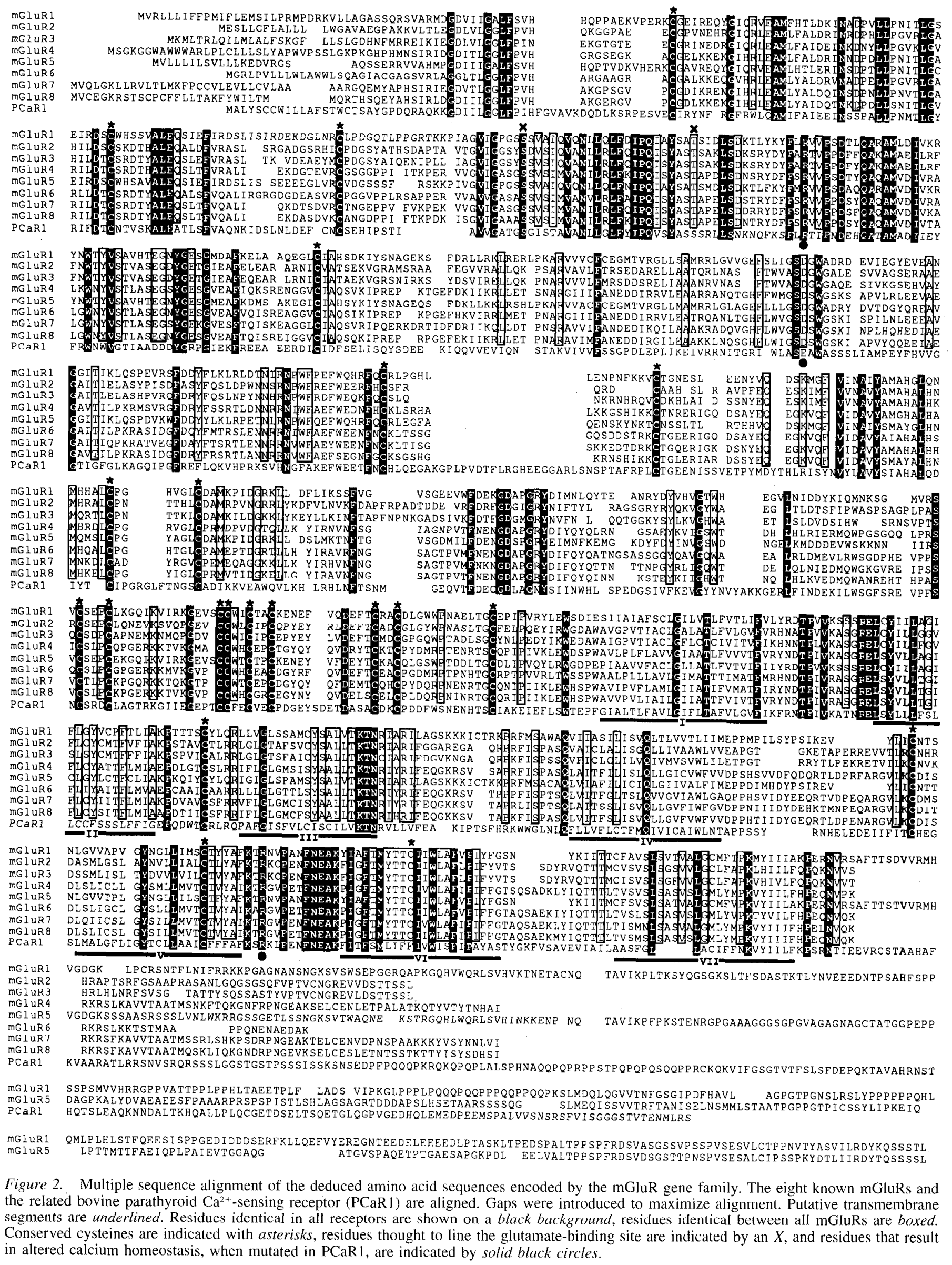




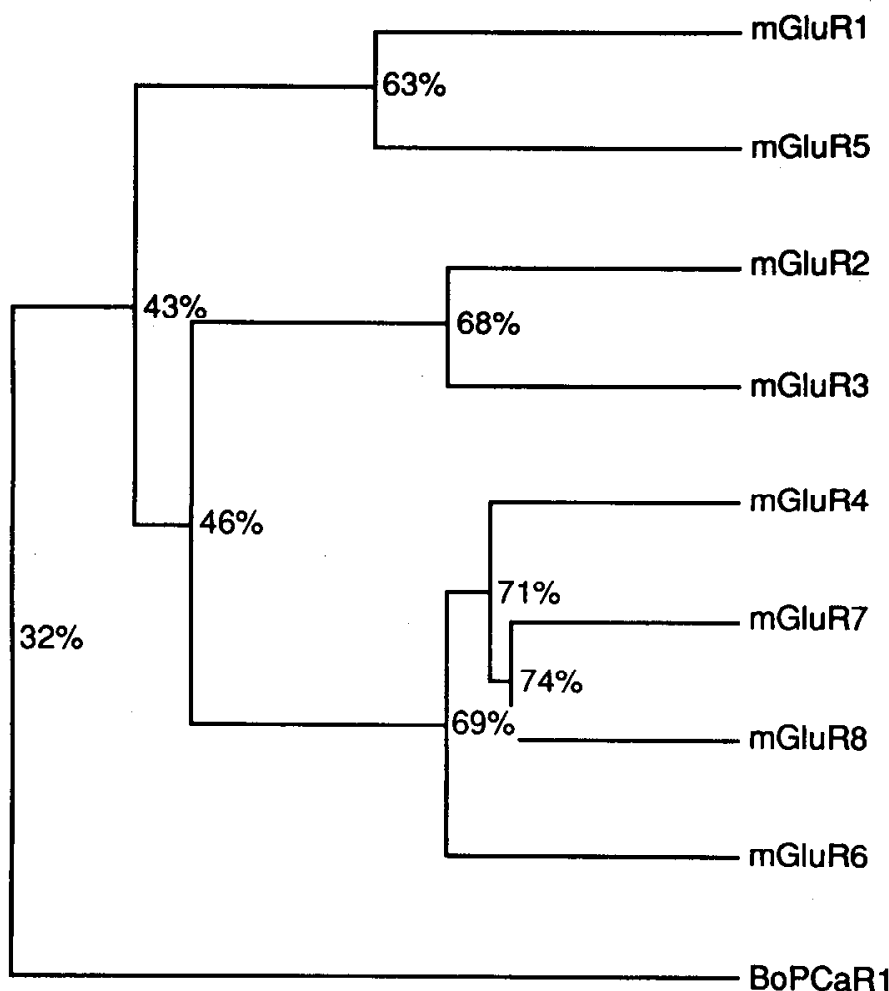

Figure 3. Schematic representation of the mGluR gene family similarity. Percent sequence identities were calculated from pairwise sequence alignments. Averages are given for comparisons between more than two sequences.

peptide, but the method of von Heijne (1986) does not predict an unambiguous cleavage site. The highest score suggests a proteolytic cleavage following the Serine residue at position 33, which would yield a mature receptor with a calculated molecular weight of 97,451. The following large amino-terminal domain is predicted to be extracellular and contains four potential $\mathrm{N}$-linked glycosylation sites. Three potential phosphorylation sites are available in the predicted cytoplasmic loops and carboxy-terminal tail (Fig. 1).

A multiple sequence alignment between all known mGluR sequences and the related $\mathrm{Ca}^{21}$-sensing receptor (Brown et al., 1993) is shown in Figure 2. The most conserved regions are a hydrophobic domain in the extracellular domain, postulated to form the ligand binding domain (O'Hara et al., 1993), and segments surrounding this region. The first and third intracellular loops, possibly involved in G-protein coupling, and several putative transmembrane segments, especially the sixth, are also very conserved between mGluRs, but not as much with the $\mathrm{Ca}^{2+}$ receptor. The 21 cysteine residues conserved in all mGluRs are also present in mGluR8.

Pairwise alignments between mGluR8 and other members of the mGluR family show that it is most related to mGluR4 (74\% sequence identity) and mGluR7 (74\%), although mGluR4 is only $69 \%$ identical to mGluR7 (Fig. 3). mGluR8 is also very similar to mGluR6, the proposed APB receptor of retinal ON bipolar cells ( $70 \%$ sequence identity). It has been found that the relative potencies of various mGluR agonists is conserved among more closely related receptors. This suggests that mGluR 8 belongs to the group III mGluRs, which respond to APB by an inhibition of forskolin-stimulated adenylyl cyclase.

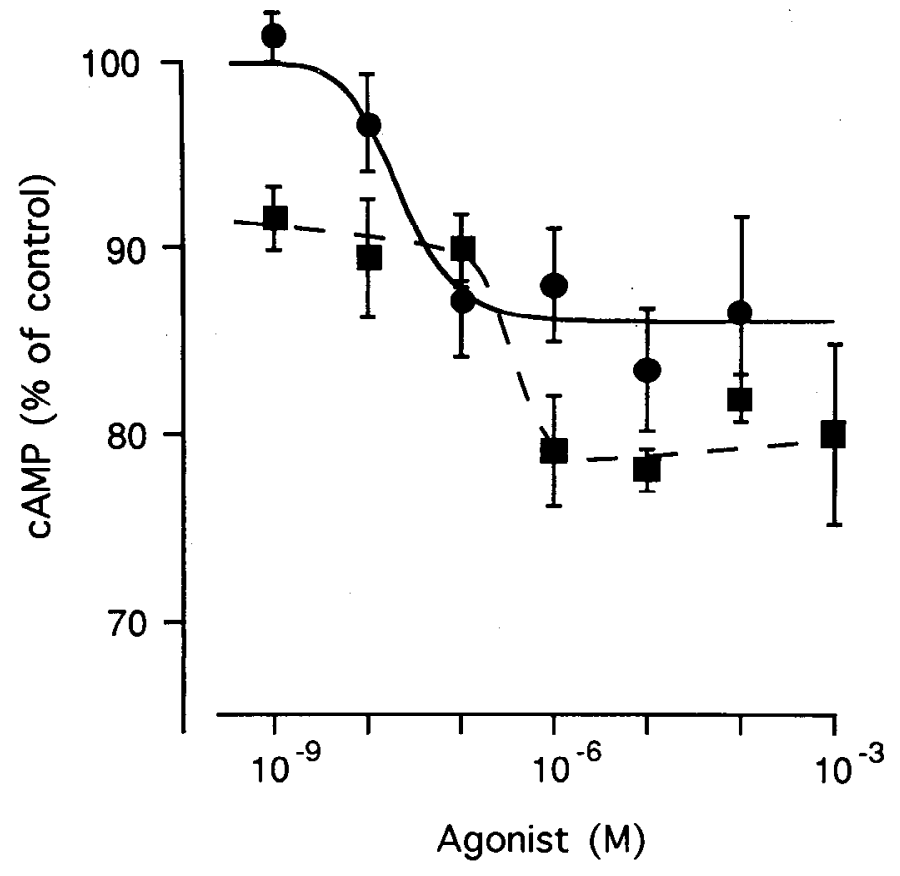

Figure 4. Dose-response curves of L-glutamate and L-APB. Inhibition of forskolin-stimulated cAMP production in mGluR8 expressing CHO cells in response to the indicated concentration of L-glutamate (O) and L-APB $(\square)$ were determined as described in Materials and Methods. Each point shows the mean \pm SD of at least three experiments measured in triplicates.

\section{Functional expression of $m G l u R 8$}

To test this hypothesis, we established stable cell lines by transfecting $\mathrm{CHO}$ cells with a plasmid in which the mGluR8 cDNA is driven by the viral CMV promoter. cAMP production in forskolin-stimulated cells in the presence and absence of several glutamate agonists was measured. Maximal inhibitions were obtained with L-APB and L-glutamate, and dose-response curves were determined for these agonists (Fig. 4). The calculated halfmaximal effective concentration $\left(\mathrm{EC}_{50}\right)$ of $\mathrm{L}$-glutamate is $22 \mathrm{nM}$. In contrast to the other group III mGluRs, it is lower than the $\mathrm{EC}_{50}$ of L-APB, which is 400 nM. Maximal inhibitions (about $20 \%$ ) are lower than reported for previously tested mGluRs. This difference could reflect a physiological difference between mGluR8 and the other mGluRs or could be due to an experimental difference, for example in the level of mGluR expression. In our control experiments, mGluR2 expressing cells had a maximal inhibition of $57 \%$, which was less than the $80 \%$ previously reported (Tanabe et al., 1992).

Other glutamate agonists tested gave smaller responses with $100 \mu \mathrm{M}$ (IS-3R)-ACPD, quisqualate, and ibotenate producing $10 \%, 7 \%$, and $7 \%$ inhibition of forskolin-stimulated cAMP formation, respectively. As control, no inhibition of adenylyl cyclase was detected in cells transfected with the selection plasmid vector $\mathrm{pSVneo}$ alone (not shown).

We also tested whether mGluR 8 could be coupled to phosphoinositol turnover in the Xenopus oocyte expression model. It has been shown that in this system, the accumulation of inositol phosphates promotes the release of $\mathrm{Ca}^{2+}$ from intracellular stores and leads to the opening of $\mathrm{Ca}^{2+}$-activated $\mathrm{Cl}^{-}$channels. $\mathrm{No} \mathrm{Cl}^{-}$ currents were recorded in response to $1 \mathrm{mM}$ glutamate in oocytes injected with mGluR8 synthetic RNA, whereas large currents were measured in a parallel experiment with mGluRl RNA- 

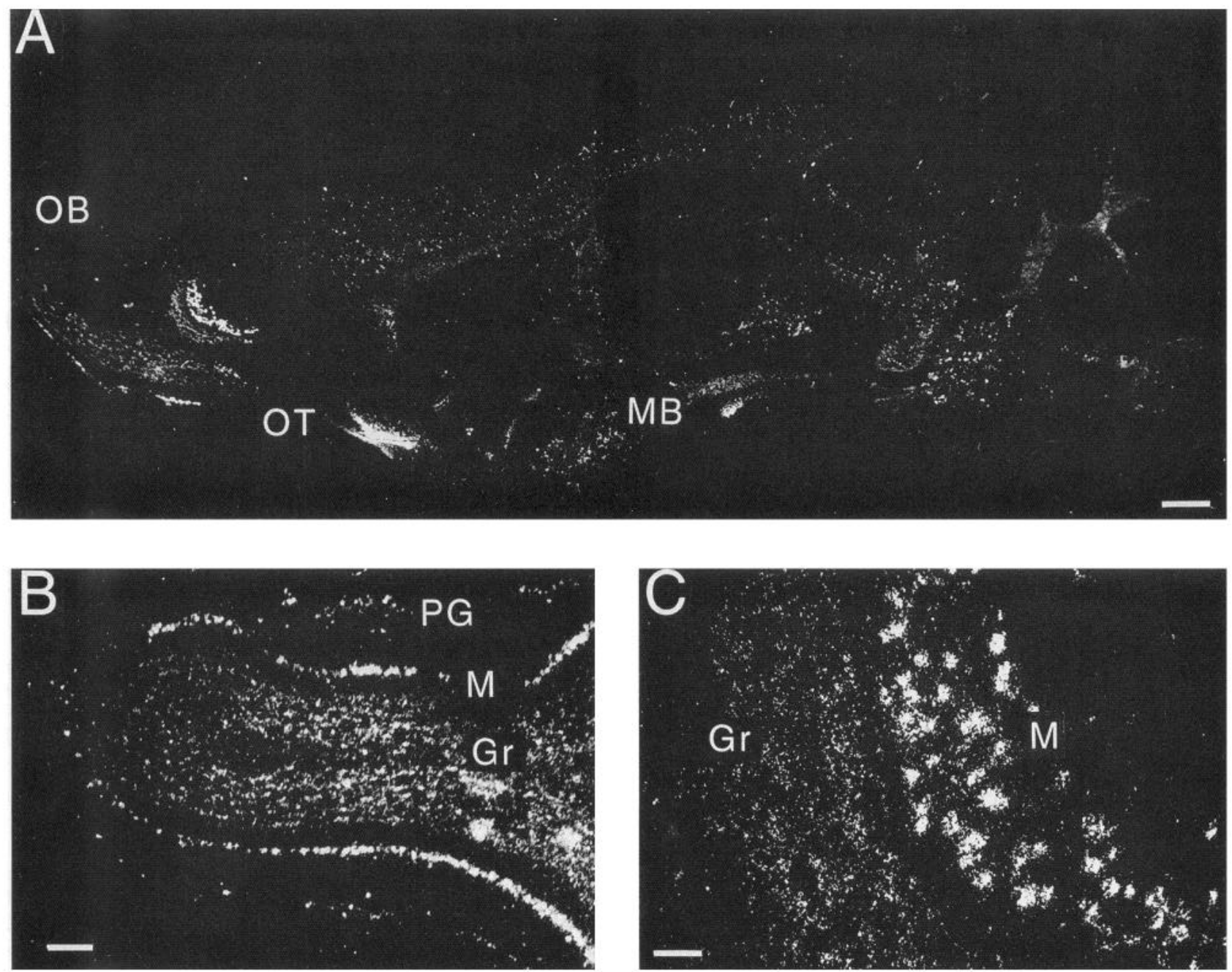

Figure 5. Distribution of mGluR8 mRNA in adult mouse CNS. A, parasagittal section of the adult brain. Labeling is detected in the olfactory bulb $(O B)$, the olfactory tubercle $(O T)$, and in the mammillary body $(M B)$. $B$, Horizontal section through the olfactory bulb. Mitral $(M)$, granule $(G)$, and periglomerular $(P G)$ cell layers are labeled. $C$, Sagittal section through the accessory olfactory bulb. Mitral $(M)$ and granule $(G)$ cells are labeled. Scale bars: $A, 500 \mu \mathrm{m} ; B, 200 \mu \mathrm{m} ; C, 50 \mu \mathrm{m}$.

injected oocytes (not shown). From these experiments we conclude that mGluR8 does not couple to phosphoinositol turnover, at least in Xenopus oocytes.

\section{Localization of expression by in situ hybridization analysis}

To determine the pattern of mGluR8 gene expression in the adult and developing brain, in situ hybridization histochemistry using a ${ }^{35}$ S-UTP-labeled antisense riboprobe was performed. A sense probe was used as negative control and to determine washing conditions. Horizontal and sagittal sections through the adult mouse brain, transversal retinal sections, and sagittal sections through the developing mouse head were hybridized with both probes. Strong expression of mGluR8 was found in the olfactory bulb, olfactory tubercle, and mammillary body (Fig. $5 A$ ). Scattered cells were also labeled in the deeper layers of the cortex and in the hindbrain. A horizontal section through the olfactory bulb reveals that cells in the granule, mitral, and periglomerular layers are expressing mGluR8 (Fig. $5 B$ ). It is possible that a few displaced tufted cells are also positive. In addition, mitral and granule cells of the accessory olfactory bulb are also strongly labeled (Fig. 5C). No expression of mGluR8 was detected in the cerebellum and in the hippocampus, two regions where APB has been shown to inhibit excitatory glutamate neurotransmission. In these regions this effect is thus likely to be mediated by mGluR4 and mGluR7 receptors.

The pattern of mGluR8 expression was also analyzed in the developing brain and in the retina (Fig. 6). A widespread expression was found in the embryonic day 16 (E16) mouse. Hybridization was visible with varying intensities in parts of the developing telencephalon, thalamus, hypothalamus, midbrain, pons, and medulla oblongata, as well as in the olfactory bulb and retina (Fig. 6A,B). Expression was also detected in the PNS, in the developing dorsal root and trigeminal ganglia. Overall, the hybridization signals appeared stronger than in the adult. This could reflect higher levels of expression during development than in the adult or a difference in permeability of the probe into developing tissue as compared to adult tissue. This observation was confirmed in a developmental series study of the retina (Fig. 6C). mGluR8 transcripts were clearly detected at E16 in the developing retina. At this stage, most cells are still actively dividing in the ventricular zone, located in the outer retina, but a few postmitotic cell have migrated towards the inner 

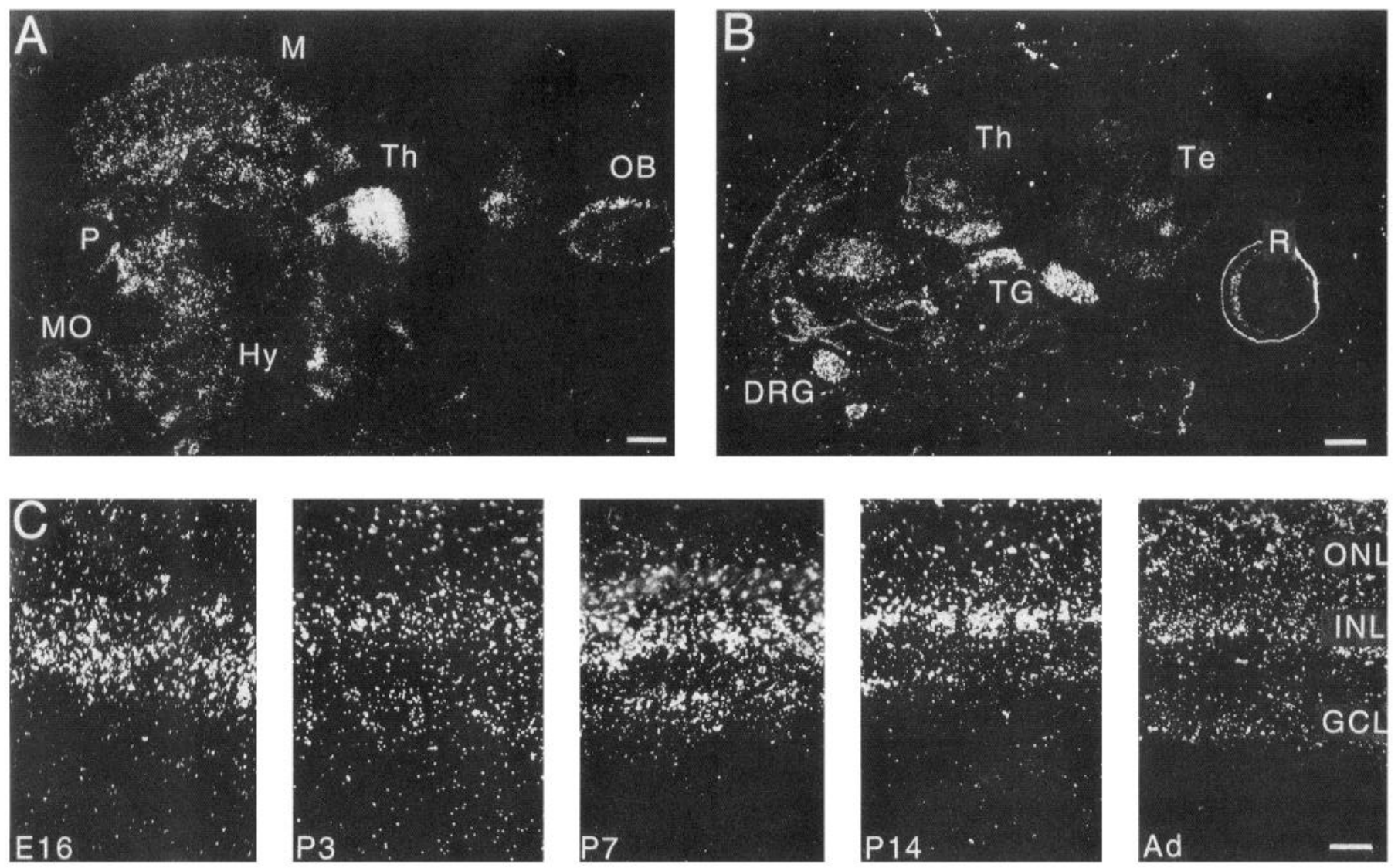

Figure 6. Distribution of mGluR8 mRNA during development. Dark-field photomicrographs of emulsion-dipped $20 \mu \mathrm{m}$ sections that were hybridized in situ with ${ }^{35} \mathrm{~S}$-radiolabeled antisense full-length mGluR8 probe (see Materials and Methods). A, Sagittal section, and $B$, parasagittal section through an E16 mouse embryo. Labeling is visible in the telencephalon $(T e)$, thalamus $(T h)$, hypothalamus $(H y)$, midbrain $(M)$, pons $(P)$, medulla oblongata $(M O)$, olfactory bulb $(O B)$, retina $(R)$, dorsal root and trigeminal ganglia $(D R G$ and $T G)$. $C$, developmental series of transverse retinal sections. Labeling is observed in the ganglion cell and inner nuclear cell layers and possibly in the outer nuclear layer, where photoreceptor cell bodies reside (GCL, INL, ONL, respectively). Scale bars: $A$ and $B, 100 \mu \mathrm{m} ; C, 25 \mu \mathrm{m}$.

retina and started to differentiate into ganglion and amacrine cells (Young, 1985a,b). Many of these cells express mGluR8. Differentiation of the retina proceeds from the center to the periphery, and it is apparent that at E16 more cells are mGluR8 positive in the central retina than in the periphery (Fig. $6 B$ ). Around birth, the ganglion cell layer (GCL) becomes separated from the inner nuclear layer (INL) by a synaptic layer, the inner plexiform layer (IPL). From then on, mGluR8 expression is visible in both the INL and GCL, at first at similar intensities. While hybridization signals stay high in the INL during differentiation of the bipolar and Müller cells, the level of expression in the GCL is reduced. In the adult, levels appear lower and about similar in the INL and GCL, but because of the poor resolution of ${ }^{35} \mathrm{~S}$-labeling it is not possible to determine in which specific cell types mGluR8 is expressed. It is possible that photoreceptor cells in the outer nuclear layer (ONL) are positive for mGluR8, but because of the low level of expression and the long exposure times necessary to detect a signal, it is difficult to determine whether the grains only reflect a higher background above these cells. When mGluR8-specific antisera become available, immunohistochemical studies might provide an answer.

\section{Discussion}

The identification of a novel metabotropic glutamate receptor, named mGluR8, is reported. This receptor is most related to the group III mGluR subfamily, which includes mGluR4, mGluR6 and mGluR7. Transfected in fibroblasts, these receptors have been shown to respond to APB stimulations by the inhibition of forskolin-stimulated adenylyl cyclase. The $\mathrm{EC}_{50}$ for L-APB of mGluR4, mGluR6, and mGluR8 is about $1 \mu \mathrm{M}$ (Thomsen et al., 1992; Nakajima et al., 1993; this work), whereas for mGluR7 it is about $160 \mu \mathrm{M}$ (Okamoto et al., 1994). For mGluR4, mGluR6 and mGluR7, the potency of L-glutamate is lower than for L-APB ( $\mathrm{EC}_{50}$ values of $27 \mu \mathrm{M}, 16 \mu \mathrm{M}$, and $1 \mathrm{~mm}$, respectively). mGluR8 is distinctive in having a reversed relative potency order for L-glutamate and L-APB.

In our experiments with mGluR8, the average maximal inhibition of forskolin-stimulated cAMP formation was only $20 \%$. This modest inhibition could be due to technical difficulties; different laboratories report widely different maximal inhibition in experiments expressing other mGluRs [compare Thomsen et al. (1992) with Tanabe et al. (1993) or Okamoto et al. (1994) with Saugstad et al. (1994)]. Such differences could be due to variations in the level of receptor expression, or in the precise experimental protocol. Even when care is taken not to include glutamate in the culture medium, metabolic glutamate could be released into it. This glutamate could activate the transfected mGluRs, and produce a growth disadvantage for cells that express the most receptors, eventually leading to cell lines expressing little functional receptor. When antibodies become available, 
it will be possible to test this hypothesis by immunoprecipitating the receptors expressed in transfected cells after different passage numbers.

Alternatively, this low efficiency of coupling could be due to the absence of the appropriate $\mathrm{G}$ protein in $\mathrm{CHO}$ cells or reflect the possibility that mGluR8 is not normally coupled to adenylyl cyclase inhibition. Various mGluRs have been proposed to inhibit cGMP-phosphodiesterase, activate or inhibit adenylyl cyclase, activate phospholipase $\mathrm{C}$ or phospholipase $\mathrm{A} 2$, or even be directly coupled to $\mathrm{Ca}^{2+}$ and $\mathrm{K}^{+}$ion channels (Trombley and Westbrook, 1992; Schoepp and Conn, 1993). Such diversity in the effector function results from the specific combination of trimeric $\mathrm{G}$ proteins available in the cell and the preferred coupling of the receptor. Furthermore, the same receptor could activate multiple pathways, for example mGluRl is coupled to phosphoinositol turnover, but also to stimulations of cAMP formation and arachidonic acid release (Aramori and Nakanishi, 1992).

\section{Metabotropic glutamate receptors in the olfactory bulb}

APB has been shown to antagonize glutamatergic neurotransmission in various parts of the CNS, such as the hippocampus, the olfactory cortex, and the spinal cord (Mayer and Westbrook, 1987). This effect is thought to result from the presynaptic activation of mGluRs, perhaps of the mGluR4 type (Tanabe et al., 1993), similar to the presynaptic depression of GABA release by olfactory granule cells following mGluR2 activation (Hayashi et al., 1993). However, the distribution of mGluR4 receptor expression is not consistent with the distribution of some of the reported physiological effects of APB, and it is likely that additional receptors could be involved. For example, the inhibitory effects of APB in the entorhinal cortex have been proposed to be mediated by mGluR7 receptors (Saugstad et al., 1994). The axons of mitral and tufted cells of the olfactory bulb form the lateral olfactory tract and project to the entorhinal cortex (Haberly and Price, 1977). The activation of presynaptic APB-sensitive mGluRs on mitral/tufted cell axons could account for the antagonist effect of APB applied to entorhinal cortex slices (Hearn et al., 1986). However, micromolar concentrations of APB applied to isolated olfactory bulb neurons were sufficient to produce an effect (Trombley and Westbrook, 1992). This is inconsistent with the low $\mathrm{EC}_{50}$ of APB on mGluR7. It is possible that mGluR8 receptors, which were shown here by in situ hybridization to be expressed in mitral/tufted cells, are responsible for the presynaptic regulation of glutamate release in the entorhinal cortex.

\section{Metabotropic glutamate receptors in retina}

In the retina, light information is encoded by processing various attributes through numerous pathways. Most prominent and basic among these pathways are the ON and OFF pathways. They signal increments and decrements of light and are established at the level of bipolar cells. Within the IPL, the ON and OFF bipolar output synapses are stratified into distinct sublaminae. This segregation, which is gradually acquired during differentiation, is thought to depend on synaptic activity. Recently, it has been shown that intraocular injections of APB during retinal differentiation in the newborn cat prevented normal stratification of the IPL (Bodnarenko and Chalupa, 1993). This finding was interpreted as resulting from the block of ON bipolar cell activity by a constant stimulation of the APB-sensitive receptor on these cells, most likely the recently cloned mGluR6 (Nakajima et al.,
1993; Nomura et al., 1994). However, we have shown here that more than one APB-activated $\mathrm{mGluR}$ is present in the retina. It is therefore possible that the effects of APB infusions during retinal development are more complex than previously thought. The activation of metabotropic receptors coupled to second messenger pathways would be expected to affect dendritic outgrowth, synaptogenesis, and synaptic pruning. Similarly, intravitreal injections of APB have been shown to influence the emmetropization process (Smith et al., 1991). The inference was made that this effect was caused by blocking the ON pathway; for the same reasons, this conclusion could be premature.

Several mGluRs are known to be expressed in the retina. mGluR1 has been localized immunohistochemically in ganglion and amacrine cells (Peng et al., 1992) and mGluR6 to rod bipolar cells (Nomura et al., 1994). We have described briefly here the identification of mGluR3 sequences among RT-PCR products using mouse retinal $\mathrm{mRN} \Lambda$ as template; and mGluR8 was isolated from retinal cDNA libraries. Aside from mGluR6, the role of these receptors in retinal function remains unclear. APB has been reported to antagonize the horizontal cell response to light (Nawy et al., 1989). This action could be caused by a presynaptic depression of transmitter release by photoreceptors, an antagonist effect on horizontal cell AMPA/kainate GluRs, or a modulation of these receptors or some other conductance through a second messenger pathway activated by APB and/or ACPD (Yang and Wl, 1991; Takahashi and Copenhagen, 1992). The resolution of in situ hybridization histochemistry is not sufficient to determine which cell types are expressing mGluR8 in the retina and whether this receptor is mediating those effects. Clearly, to better understand the role of mGluRs in the development and function of the CNS, receptor subtype specific tools, such as specific antibodies, agonists, and antagonists, are needed.

\section{References}

Abe T, Sugihara H, Nawa H, Shigemoto R, Mizuno N, Nakanishi S (1992) Molecular characterization of a novel metabotropic glutamate receptor mGluR5 coupled to inositol phosphate/ $\mathrm{Ca}^{2+}$ signal transduction. J Biol Chem 267:13361-13368

Aramori I, Nakanishi S (1992) Signal transduction and pharmacological characteristics of a metabotropic glutamate receptor, mGluR 1 , in transfected CHO cells. Neuron 8:757-765.

Bodnarenko SR, Chalupa LM (1993) Stratification of ON and OFF ganglion cell dendrites depends on glutamate-mediated activity in the developing retina. Nature 364:144-146.

Bowes C, Danciger M, Kozak CA, Farber DB (1989) Isolation of a candidate cDNA for the gene causing retinal degeneration in the $r d$ mouse. Proc Natl Acad Sci USA 86:9722-9726.

Brown EM, Gamba G, Riccardi D, Lombardi M, Butters R, Kifor O, Sun A, Hediger MA, Lytton J, Hebert SC (1993) Cloning and characterization of an extracellular $\mathrm{Ca}^{2+}$-sensing receptor from bovine parathyroid. Nature 366:575-580.

Chen W-J, Andres DA, Goldstein JL, Russel DW, Brown MS (1991) cDNA cloning and expression of the peptide-binding $\beta$ subunit of rat p21 ras fanesyltransferase, the counterpart of yeast DPR1/RAM1. Cell 66:327-334

Cox KH, De Leon DV, Angerer LM, Angerer RC (1984) Detection of mRNAs in sea urchin embryos by in situ hybridization using asymmetric RNA probes. Dev Biol 101:485-502.

Devereux J, Haeberli P, Smithies O (1984) A comprehensive set of sequence analysis programs for the VAX. Nucleic Acids Res 12:387395.

Duvoisin RM, Deneris ES, Patrick J, Heinemann S (1989) The functional diversity of the neuronal nicotinic acetylcholine receptors is increased by a novel subunit: $\beta 4$. Neuron $3: 487-496$.

Haberly LB. Price JL (1977) The axonal projection patterns of the mitral and tufted cells of the olfactory bulb in the rat. Brain Res 129: 152-157. 
Hayashi Y, Momiyama A, Takahashi T, Ohishi H, Ogawa-Meguro R, Shigemoto R, Mizuno N, Nakanishi S (1993) Role of a metabotropic glutamate receptor in synaptic modulation in the accessory olfactory bulb. Nature 366:687-690.

Hearn TJ, Ganong AH, Cotman CW (1986) Antagonism of lateral olfactory tract synaptic potentials in rat prepyriform cortex slices. Brain Res 379:372-376.

Hollmann M, Heinemann SH (1994) Cloned glutamate receptors. Annu Rev Neurosci 17:31-108.

IIouamed KM, Kuijper JL, Gilbert TL, IIaldeman BA, O'IIara PJ, Mulvihill ER, Almers W, Hagen FS (1991) Cloning, expression, and gene structure of a G-protein-coupled glutamate receptor from rat brain. Science 252:1318-1321.

Hughes TE, Hermans-Borgmeyer I, Heinemann S (1992) Differential expression of glutamate receptor genes (GluR1-5) in the rat retina. Vis Neurosci 8:49-55.

Kozak M (1986) Point mutations define a sequence flanking the AUG initiation codon that modulates translation by eukaryotic ribosomes. Cell 44:283-292.

Masu M, Tanabe Y, Tsuchida K, Shigemoto R, Nakanishi S (1991) Sequence and expression of a metabotropic glutamate receptor. Nature 349:760-765.

Mayer ML, Westbrook GL (1987) The physiology of excitatory amino acids in the vertebrate central nervous system. Prog Neurobiol 28: 197-276.

Monaghan DT, Bridges RJ, Cotman CW (1989) The excitatory amino acid receptors: their classes, pharmacology and distinct properties in the function of the central nervous system. Annu Rev Pharmacol Toxicol 29:365-402.

Nakajima Y, Iwakabe H, Akazawa C, Nawa H, Shigemoto R, Mizuno $\mathrm{N}$, Nakanishi S (1993) Molecular characterization of a novel retinal metabotropic glutamate receptor mGluR6 with a high agonist selectivity for L-2-amino-4-phosphonobutyrate. J Biol Chem 268:1186811873.

Nakanishi S (1992) Molecular diversity of glutamate receptors and implications for brain function. Science 258:597-603.

Nawy S, Sie A, Copenhagen DR (1989) The glutamate analog 2-amino-4-phosphonobutyrate antagonizes synaptic transmission from cones to horizontal cells in the goldfish retina. Proc Natl Acad Sci USA 86:1726-1730.

Nomura A, Shigemoto R, Nakamura Y, Okamoto N, Mizuno N, Nakanishi S (1994) Developmentally regulated postsynaptic localization of a metabotropic glutamate receptor in rat rod bipolar cells. Cell 77: 361-369.

O'Hara PJ, Sheppard PO, Thogersen H, Venezia D, Hadelman BA, McGranc V, Houamed KM, Thomsen C, Gilbert TL, Mulvihill ER (1993) The ligand-binding domain in metabotropic glutamate receptors is related to bacterial periplasmic binding proteins. Neuron 11 : 41-52.

Okamoto N, Hori S, Akazawa C, Hayashi Y, Shigemoto R, Mizuno N, Nakanishi S (1994) Molecular characterization of a new metabotropic glutamate receptor mGluR7 coupled to inhibitory cyclic AMP signal transduction. J Biol Chem 269:1231-1236.
Peng Y-W, Blackstone CD, Huganir RL, Yau K-W (1992) Distribution of glutamate receptors subtypes in rat retina. Invest Ophthalmol Vis Sci 33:1174.

Sambrook J, Fritsch EF, Maniatis T (1986) Molecular cloning. Plainview, NY: Cold Spring Harbor Laboratory.

Saugstad JA, Kinzie JM, Mulvihill ER, Segerson TP, Westbrook GL (1994) Cloning and expression of a new member of the L-AP4sensitive class of metabotropic glutamate receptors. Mol Pharmacol 45:367-372.

Schiller PH (1992) The ON and OFF channels of the visual system. Trends Neurosci 15:86-92.

Schoepp DD, Conn PJ (1993) Metabotropic glutamate receptors in brain function and pathology. Trends Neurosci 14:13-20.

Seeburg PH (1993) The molecular biology of mammalian glutamate receptor channels. Trends Neurosci 14:297-303.

Short JM, Fernandez JM, Sorge JA, Huse WD (1988) Lambda ZAP: a bacteriophage lambda expression vector with in vivo excision properties. Nucleic Acids Res 16:7583-7600.

Slaughter MM, Miller RF (1981) 2-Amino-4-phosphonobutyric acid: a new pharmacological tool for retina research. Science 211:182-185.

Smith EL III, Fox DA, Duncan GC (1991) Refractive-error changes in kitten eyes produced by chronic ON-channel blockade. Vision Res 31:833-844.

Southern PJ, Berg P (1982) Transformation of mammalian cells to antibiotic resistance with a bacterial gene under the control of the SV40 early region promoter. J Mol Appl Genet 1:327-341.

Spengler D, Wacber C, Pantaloni C, Holboer F, Bockaert J, Seeburg PH, Journot L (1993) Differential signal transduction by five splice variants of the PACAP receptor. Nature 365:170-175.

Takahashi K, Copenhagen DR (1992) APB suppresses syrlaptic input to retinal horizontal cells in fish: a direct action on horizontal cells modulated by intracellular pH. J Neurophysiol 67:1633-1642.

Tanabe Y, Masu M, Ishii 'I, Shigemoto R, Nakanishi S (1992) A family of metabotropic glutamate receptors. Neuron 8:169-179.

Tanabe Y, Nomura A, Masu M, Shigemoto R, Mizuno N, Nakanishi S (1993) Signal transduction, pharmacological properties, and expression patterns of two rat metabotropic glutamate receptors, mGluR3 and mGluR4. J Neurosci 13:1372-1378.

Thomsen C, Kristensen P, Mulvihill E, Haldeman B, Suzdack PD (1992) L-2-Amino-4-phosphonobutyrate (L-AP4) is an agonist at the type IV metabotropic glutamate receptor which is negatively coupled to adenylate cyclase. Eur J Pharmacol 227:361-362.

Trombley PQ, Westbrook GL (1992) L-AP4 inhibits calcium currents and synaptic transmission via a G-protein-coupled glutamate receptor. J Neurosci 12:2043-2050.

von Heijne G (1986) A new method for predicting signal sequence cleavage sites. Nucleic Acids Res 14:4683-4690.

Yang XL, Wu SM (1991) Coexistence and function of glutamate receptor subtypes in the horizontal cells of the tiger salamander retina. Vis Neurosci 7:377-38'2.

Young RW (1985a) Cell differentiation in the retina of the mouse. Anat Rec 212:199-205.

Young RW (1985b) Cell proliferation during postnatal development of the retina in the mouse. Brain Res 353:229-239. 